\title{
Milk production and quality of Etawa crossbreed dairy goat that given Tithonia diversifolia, corn waste and concentrate based palm kernel cake
}

\author{
ARIEF", RUSDIMANSYAH, SIMEL SOWMEN, RONI PAZLA, RIZQAN \\ Department of Livestock Production, Faculty of Animal Science, Universitas Andalas. Jl. Raya Unand, Limau Manis, Padang 25146, West Sumatra, \\ Indonesia. Tel.: +62-751-71464, ^email: aarief@ansci.unand.ac.id
}

Manuscript received: 27 May 2020. Revision accepted: 8 August 2020.

\begin{abstract}
Arief, Rudimansyah, Sowmen S, Rizqan RP. 2020. Milk production and quality of Etawa crossbreed dairy goat that given Tithonia diversifolia, corn waste and concentrate based palm kernel cake. Biodiversitas 21: 4004-4009. The research aims to evaluate the production and quality of goat milk of Etawa crossbreed dairy goat (ECDG) which is fed by Tithonia diversifolia (T), corn waste (CW), and concentrate-based palm kernel cake (CBP),. The experimental design used in this study was a completely random design (CRD) with four times treatment rations and five times replications. There are five treatments used in this research which are; treatment $\mathrm{A}$ used $60 \% \mathrm{~T}+$ $40 \%$ tofu-dregs; B used $60 \% \mathrm{~T}+20 \%$ tofu-dregs $+20 \% \mathrm{CBP}$; C used $45 \% \mathrm{~T}+15 \% \mathrm{CW}+20 \%$ tofu-dregs $+20 \% \mathrm{CBP} ; \mathrm{D}$ used $30 \% \mathrm{~T}+$ $30 \% \mathrm{CW}+20 \%$ tofu-dregs $+20 \%$ CBP. The data were analyzed by Analysis of Varian (ANOVA) and Duncan's Multiple Range Test (DMRT) for further tests. The parameters measured were milk production and milk quality, which covers dry matter, water content, protein, fat, solid non-fat, and lactose. The result showed that the treatment gave no significant effect $(\mathrm{P}>0.05)$ of milk production, dry matter, protein, fat, solid non-fat, and lactose. The study concluded that the use of $T$. diversifolia, corn-waste, and CBP could maintain milk production quality.
\end{abstract}

Keywords: Concentrate, corn waste, Etawa, milk production, quality, Tithonia diversifolia

\section{INTRODUCTION}

Milk is the secreted fluid of the mammary glands of female mammals. It contains almost all the nutrients needed for their daily needs such as protein, glucose, fat, etc. Goat is one of the domesticated animals for milk production and human benefits since 8,000 BC (Sepe and Arguello 2019). In Indonesia, the price of goat milk per liter is far more expensive than cows. One liter of goat milk reaches Rp. 60.000 while cows milk (fresh milk) is only Rp.12.000. This price difference is due to the quality of goat milk is better than cows milk. The quality of milk can be seen from the value of protein, fat, and minerals found in milk. Medium Chain Triglycerides, more in goat milk, have been recognized as lipids with unique health benefits. The soft curd of goat milk may be an advantage for adult humans suffering from gastrointestinal disturbances and ulcers. Goat milk is recommended for infants, old and convalescent people. The consumer acceptance of goat milk and its products is reported to be excellent (Bhattarai 2014).

The Etawa Crossbreed Dairy Goat (ECDG) is one of the most numerous milk-producing goats in Indonesia. ECDG is an indigenous livestock goat of Indonesia, especially for dairy goats. ECDG comes from the crossing of Etawa goats from India with local Indonesian goats, namely "Kacang Goat". The ECDG is alternative livestock to meet the milk needs of the community aside from dairy cows. Several studies have been carried out stating that goat milk is quite popular; this is caused by the fat globules found in goat milk having a smaller and homogeneous size
(Arief et al. 2018a).

The quality of milk produced from these goats fluctuates according to the type of feed given. ECDG fed with forage (Pennisetum purpureum and Calliandra calothyrsus) and concentrates that was formulated of wheat pollard, copra meal, soybean meal, corn bran, and minerals produce a milk protein value of $3.64 \%$ and milk fat of $5.80 \%$ (Suranindyah et al. 2018). whereas ECDG is fed from palm kernel cake, palm oil sludge, corn, rice bran, coconut meal, and mineral produce a milk protein value of $4.26 \%$ and milk fat of $5.45 \%$ (Arief et al. 2018a). Differences in the amount of fat and protein content of goat milk also result in differences in prices on the market. The higher the fat content and protein of goat's milk, the price will increase.

Milk quality is very dependent on the type of feed used in dairy farming. Generally, farmers in developing countries have minimal sources of feed for their domestic animals. Limited sources of forage or field grass originating from the surrounding environment with low nutritional quality affect productivity. The source of feed used by farmers is usually challenging to digest. It has a low protein content, so it is significant to improve the quality of feed and explore new kind feed sources to increase the quality of milk.

Tithonia diversifolia and corn waste are an alternative forage feed besides grass for dairy goats, which are abundant and have good nutrition content. Arief et al. (2018b) reported In West Sumatra, Indonesia; $T$. diversifolia can produce $30 \mathrm{t}$ of fresh material or $6 \mathrm{t}$ of dry matter per year in a land area of approximately $1 / 5$ ha. The 
production of dry matter from corn waste is $623,938.3$ $\mathrm{kg} / \mathrm{ha}$. T. diversifolia plant has high protein content $(22.98 \%)$ and can increase rumen microbial protein synthesis (Pazla et al. 2018a). Jamarun et al. (2019) reported the result of in vitro test on the digestibility of dry matter and organic matter showed that $T$. diversifolia plants were better than elephant grass. The increasing level of $T$. diversifolia given for ECDG could maintain the milk quality (Arief et al. 2018b; Jamarun et al. 2020), corn waste contains high total digestible nutrient (TDN) about $67 \%$. TDN is a significant factor that arranges the complete feed. The combination of $T$. diversifolia and corn waste enables the best digestibility in in-vitro study (Arief et al. 2019a)

Palm kernel cake is un-conventional feed material that can be used as animal feed (Abdeltawab and Khattab 2018). Furthermore, the potential of CBP as feed consists of $12.36 \%$ crude protein, $26.68 \%$ crude fiber $8.23 \%$ fat, and $65.40 \%$ TDN (Pazla et al. 2018b). The protein in palm kernel cake has good quality, and the concentrate of palm kernel cake has been widely tested on ECDG, and the results show that it can maintain the quality of milk (Arief et al. 2019b). This research aimed to see the effect of $T$. diversifolia, corn waste, and concentrate based palm kernel cake on the milk quality of ECDG.

\section{MATERIALS AND METHODS}

This research has been carried out on Rantiang Ameh's dairy goat farms in Agam District, West Sumatra Province, Indonesia, and Bukittinggi Veterinary Laboratory. this study used 20 dairy goats (ECDG) with ages 1,5 to 2,5 years, at lactation and lactation months 1 and 2 . These animals are divided based on ration treatment consisting of Tithonia diversifolia and corn waste as forages and tofu dregs and CBP as a concentrate. T. diversifolia and tofu dregs are control rations (A). The amount of ration given is $4 \%$ body weight in the form of dry matter. Dietary $T$. diversifolia, corn waste, and CBP levels of the experimental diets are presented in Table 1, while details of the CBP formula and nutrient profile are presented in Table 2 .

\section{Feeding Regimen and Manajemen}

Feeding was done twice a day, namely in the morning at 8:00 and the afternoon at 15.00. The feed consists of forage $T$. diversifolia, and corn waste (leaves and stems) withered one day before being given to livestock, The concentrate consists of tofu dregs as control and CBP as a treatment. The ratio of forages and concentrates was 60: 40. water was given ad-libitum. ECDG were placed in individual cages and milked twice a day, namely in the morning at 07.00 and afternoon at 14.00. Milking is done by hand, and before the milking begins, the goat udder was cleaned with iodine liquid.
Table 1. Tithonia diversifolia, corn waste and CBP contents of the experimental rations

\begin{tabular}{ccccc}
\hline \multirow{2}{*}{ Treatment } & \multicolumn{2}{c}{ Forages } & \multicolumn{2}{c}{ Concentrate } \\
\cline { 2 - 5 } & $\begin{array}{c}\text { Tithonia } \\
\text { diversifolia }\end{array}$ & $\begin{array}{c}\text { corn } \\
\text { waste }\end{array}$ & $\begin{array}{c}\text { Tofu } \\
\text { dregs }\end{array}$ & CBP \\
\hline A & $60 \%$ & - & $40 \%$ & - \\
B & $60 \%$ & - & $20 \%$ & $20 \%$ \\
C & $45 \%$ & $15 \%$ & $20 \%$ & $20 \%$ \\
D & $30 \%$ & $30 \%$ & $20 \%$ & $20 \%$ \\
\hline
\end{tabular}

Table 2. Composition of the CBP and its associated nutrient profile (DM basis)

\begin{tabular}{ll}
\hline Ingredients & Inclusion levels $(\%)$ \\
\hline Palm kernel cake & 40.00 \\
Rice bran & 20.00 \\
Corn & 9.00 \\
Tofu dregs & 30.00 \\
Mineral & 1.00 \\
Chemical composition of & Ration $(\boldsymbol{\%})$ \\
$\quad$ Dry matter & 90.19 \\
Ash & 4.41 \\
Crude protein & 13.78 \\
Crude fiber & 13.32 \\
\hline
\end{tabular}

\section{Sample collection and laboratory analysis}

This research for milk production collected for 30 days. Milk sampling was carried out twice, namely on day 20th and 30th. Milk was taken from each experimental animal as much as $200 \mathrm{ml}$. Milk samples were put into cool boxes and taken directly to the Bukittinggi Veterinary Laboratory for milk quality testing. Milk quality measured as dry matter, protein, fat, solid non-fat, and lactose. Milk quality was analyzed using the method by Sudarmadji et al. (2006). Proximate composition of feed and orts samples was analyzed following standard procedures, according to the Association of Official Analytical Chemists (AOAC 2000).

\section{Statistical analysis}

This research was conducted by an experimental method using a completely random design (CRD) with four treatment rations and five times replications. The data thus collected on dry matter, protein, fat, solid non-fat (SNF), and lactose were statistically analyzed using ANOVA (Steel and Torry 2002). Means were compared for the significance of difference using the Duncan Multiple Range Test (Steel and Torry 2002). Differences were declared significant at $\mathrm{P}<0.05$.

\section{RESULTS AND DISCUSSION}

Data milk production and quality of ECDG, which is fed with Tithonia diversifolia, corn waste, and CBP, are presented in Table 3 and 4. 


\section{Milk production}

Results of the analysis of variance showed that the treatment had no significant effect $(\mathrm{P}>0.05)$ in increasing daily milk production. These results reflect the combination of CBP, $T$. diversifolia, and corn waste that can be used as an alternative feed in maintaining daily milk production. Non-significant differences between treatments A, B, C, and $\mathrm{D}$ due to nutrient digestibility of all treatments also did not differ (Table 2). This is influenced by the availability of nutrients for the formation of milk components as well; the crude protein consumed by ECDG will be a precursor in the formation of $\mathrm{NH}_{3}$ in the rumen.

The yield of milk production increased with the combination of CBP, $T$. diversifolia, and corn waste in the ration, although it was not statistically significant. This proves CBP, T. diversifolia, and corn waste can optimize milk production. The increase in milk production is in line with the combination of several protein feed ingredients in the ration of donations from CBP, $T$. diversifolia, and corn waste to maintain cells in the mammary gland and the production of hormones and enzymes that play a role in milk biosynthesis. Tannins in $T$. diversifolia also play a role in protecting the protein from rumen degradation by forming complex bonds of protein-tannin so that the protein is not degraded in the rumen. This protein will reach the small intestine so that the animal's body can be utilized optimally for milk production needs. Milk production of ECDG, which is given T. diversifolia, corn waste, and CBP, can be seen in Figure 1.

\section{Milk protein}

Data of protein milk goat in treatments can be seen in Table 4. The result of the statistical analysis showed that the treatments did not significantly affect milk protein $(\mathrm{P}>0.05)$. It shows that the protein valued of goat milk, which was given a combination treatment of $T$. diversifolia, corn waste, and CBP, did not change. The same result was also reported that the protein of goat milk from ECDG, which was given different fed consist of $T$. diversifolia, elephant grass, and concentrate from palm kernel cake, tofu dregs, corn, and bran did not change the protein level about $4.03 \%-4.39 \%$ (Pazla et al. 2018a).

The results showed that the protein content obtained was in accordance with the research results Suranindyah et al. (2018) was 3.64\% with goat feed consisting of forage (Pennisetum purpureum and Calliandra calothyrsus) and concentrates that was formulated of wheat pollard, copra meal, soybean meal, corn bran, and mineral. Given that protein levels did not show a significant difference, it can be concluded that the combination of $T$. diversifolia, corn waste, and CBP can be used by farmers to obtain good milk protein for human health. Nutrients in the form of protein molecules which will be broken down into amino acids can be maximally available for the process of absorption into the body as material to build body cells, repair damaged tissue, and growth. Also, protein is determined as the substance in the body that functions as a builder (structural proteins, e.g., collagen, elastin), regulator (catalytic proteins, e.g., enzymes) and transport (transport proteins, e.g., hemoglobin, myoglobin, albumin, transferrin) (Vasudevan et al. 2011). Milk protein of ECDG which is given $T$. diversifolia, corn waste, and CBP can bee is seen in Figure 2

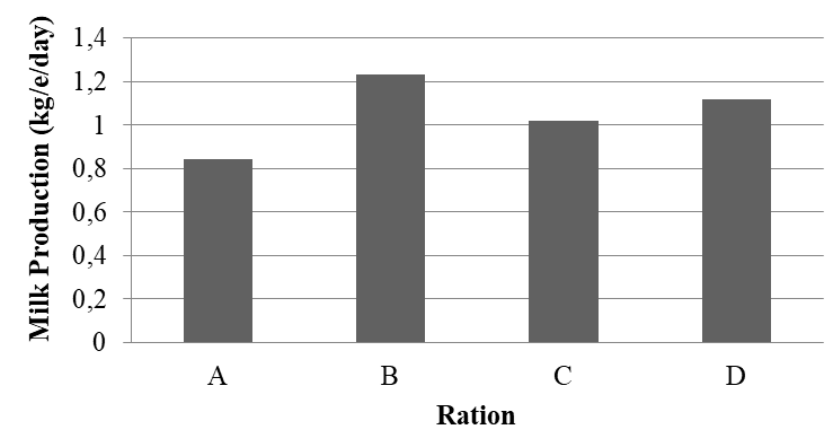

Figure 1. Milk Production of ECDG milk, which is given Tithonia diversifolia, corn waste, and CBP. Note: A (60\% T. diversifolia $+40 \%$ tofu-dregs), B (60\% T. diversifolia $+20 \%$ tofu-dregs $+20 \% \mathrm{CBP}), \mathrm{C}(45 \% \mathrm{~T}$. diversifolia $+15 \%$ corn waste $+20 \%$ tofu-dregs $+20 \% \mathrm{CBP}), \mathrm{D}(30 \%$ T. diversifolia + $30 \%$ corn waste $+20 \%$ tofu-dregs $+20 \%$ CBP)

Table 3. Milk Production of ECDG, which is given Tithonia diversifolia, corn waste, and concentrate-based palm kernel cake.

\begin{tabular}{cc}
\hline Treatments & Milk production (kg/e/day) \\
\hline A & $0.84 \pm 0.26$ \\
B & $1.23 \pm 0.17$ \\
C & $1.02 \pm 0.55$ \\
D & $1.12 \pm 0.41$ \\
\hline
\end{tabular}

Note: A (60\% Tithonia diversifolia $+40 \%$ tofu-dregs), B $(60 \%$ T. diversifolia $+20 \%$ tofu-dregs $+20 \% \mathrm{CBP})$, C (45\% T. diversifolia $+15 \%$ corn waste $+20 \%$ tofu-dregs $+20 \%$ CBP $), \mathrm{D}$ (30\% T. diversifolia $+30 \%$ corn waste $+20 \%$ tofu-dregs $+20 \%$ CBP)

Table 4. Quality of ECDG milk which is given Tithonia diversifolia, corn waste, and concentrate-based palm kernel cake

\begin{tabular}{|c|c|c|c|c|}
\hline \multirow{2}{*}{ Parameters (\%) } & \multicolumn{4}{|c|}{ Treatments } \\
\hline & $\mathbf{A}$ & B & $\mathbf{C}$ & D \\
\hline Protein & $3.86 \pm 0.07$ & $3.69 \pm 0.02$ & $3.74 \pm 0.07$ & $3.71 \pm 0.06$ \\
\hline Fat & $7.70 \pm 1.43$ & $7.13 \pm 1.39$ & $7.12 \pm 1.12$ & $8.04 \pm 1.10$ \\
\hline SNF & $8.21 \pm 0.16$ & $7.90 \pm 0.06$ & $7.95 \pm 0.14$ & $7.08 \pm 1.12$ \\
\hline Lactose & $3.89 \pm 0.13$ & $3.72 \pm 0.07$ & $3.75 \pm 0.06$ & $3.77 \pm 0.10$ \\
\hline Dry matter & $15.91 \pm 1.58$ & $15.03 \pm 1.41$ & $15.07 \pm 1.08$ & $15.12 \pm 1.54$ \\
\hline
\end{tabular}

Note: A (60\% Tithonia diversifolia $+40 \%$ tofu-dregs), B (60\% T. diversifolia $+20 \%$ tofu-dregs $+20 \%$ CBP), C (45\% T. diversifolia $+15 \%$ corn waste $+20 \%$ tofu-dregs $+20 \% \mathrm{CBP}), \mathrm{D}(30 \%$ T. diversifolia $+30 \%$ corn waste $+20 \%$ tofu-dregs $+20 \% \mathrm{CBP})$ 


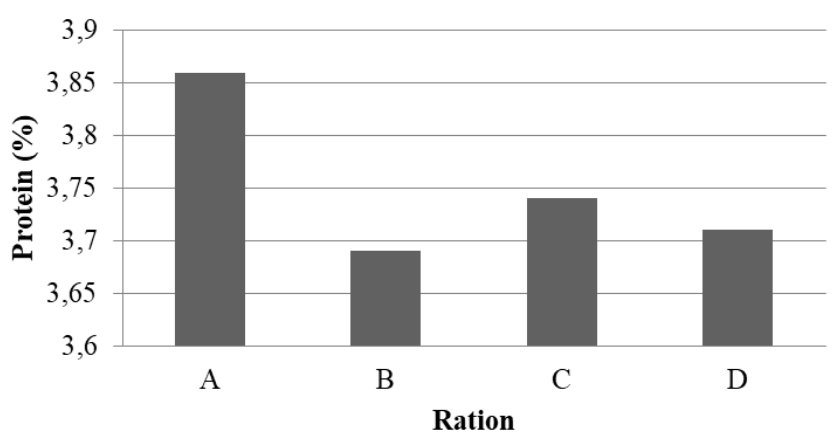

Figure 2. Milk protein of ECDG milk which is given Tithonia diversifolia, corn waste, and CBP. Note: A $60 \%$ Tithonia diversifolia $+40 \%$ tofu-dregs $),$ B $(60 \%$ T. diversifolia $+20 \%$ tofu-dregs $+20 \% \mathrm{CBP}), \mathrm{C}(45 \% \mathrm{~T}$. diversifolia $+15 \%$ corn waste $+20 \%$ tofu-dregs $+20 \%$ CBP $), \mathrm{D}(30 \%$ T. diversifolia + $30 \%$ corn waste $+20 \%$ tofu-dregs $+20 \%$ CBP)

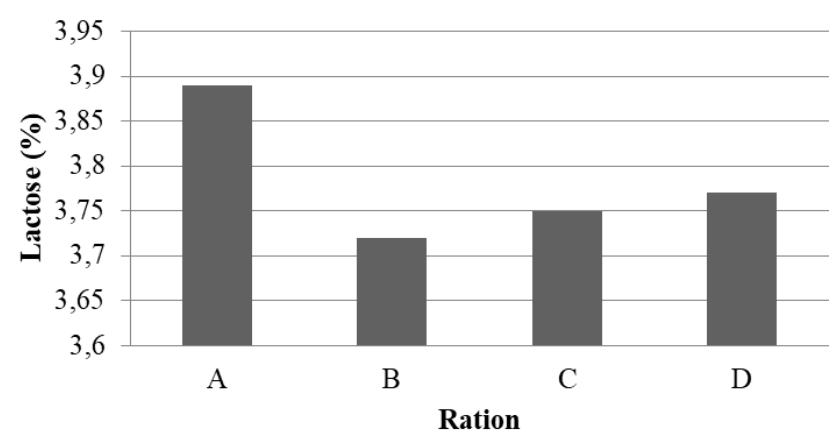

Figure 3. Milk lactose of ECDG milk which is given Tithonia diversifolia, corn waste and CBP. Note: A $(60 \%$ Tithonia diversifolia $+40 \%$ tofu-dregs $)$, B $(60 \%$ T. diversifolia $+20 \%$ tofu-dregs $+20 \% \mathrm{CBP}), \mathrm{C}(45 \% \mathrm{~T}$. diversifolia $+15 \%$ corn waste $+20 \%$ tofu-dregs $+20 \% \mathrm{CBP}), \mathrm{D}(30 \%$ T. diversifolia + $30 \%$ corn waste $+20 \%$ tofu-dregs $+20 \%$ CBP)

\section{Milk lactose}

The use of a combination of $T$. diversifolia, corn waste, and CBP in the treatment had no significant effect $(\mathrm{P}>$ 0.05 ) on lactose content of ECDG goat milk (Table 3). Milk lactose level obtained from this study ranged from 3 . 72 to $3.89 \%$. This result is lower than that of Utari et al. (2012), which is $4.05 \%$, and higher than the results by Dharmawan et al. (2019) 2.92-3.41\%. The levels of lactose $\mathrm{B}, \mathrm{C}$, and D, are the same as A, this is caused by the protein content of feed in the treatment $\mathrm{B}, \mathrm{C}$, and D are still able to meet the needs of the goat and the same as the control treatment (A). Feed protein will be remodeled into amino acids that are absorbed in the intestine to be converted into glucose in the liver through the process of gluconeogenesis, thereby increasing glucose levels in the blood and then increasing milk lactose levels.

Tithonia diversifolia and corn waste are preferred by goats so that they can increase feed consumption. Besides, the palm kernel cake used has been sifted beforehand so that a smooth palm kernel cake is obtained without any shell or hard parts with high lignin. High lignin complicates the process of feed digestion. Low lignin will make it easier for rumen microbes to digest the food that results in increasing feed consumption, especially protein digestibility, which will ultimately stimulate livestock to consume more feed (Pazla et al. 2018b). High feed consumption results in the availability of substrates needed for milk lactose synthesis, namely glucose. Carbohydrates are easily digested in the rumen and fermented into volatile fatty acid, propionic acids. The propionic acid then undergoes gluconeogenesis in the liver to form glucose, which will be carried by the blood to the udder secretory cells to be used as raw material for milk lactose synthesis. The high ratio between propionic acid and acetic acid will increase lactose production and lactose synthesis is facilitated by the enzyme lactose synthetase. According to Sunehag et al. (2002) and Rigout et al. (2002), in the study of Y. Zhang et al. (2018) stated that as the main substrate for lactose synthesis, glucose contributes around $80 \%$ of carbon in lactose in humans and $85 \%$ in cattle.

Lactose is one of the most significant components of milk, and its main precursor is blood glucose. In the mammary gland, the glucose molecule phosphorates from glucose 6-phosphate to glucose 1-phosphate. Glucose phosphate with uridine triphosphate (UTP) forms glucose diphosphate (UDP). UDP glucose is then converted to galactose UDP. UDP glucose, along with free glucose, forms lactose with the release of UDP; then, lactose synthesis is catalyzed by the enzyme lactose synthetase. Moreover, it is stated that lactose production influences osmotic pressure between blood and milk lumen. The high osmotic pressure on the lumen of milk due to high lactose production causes the flow of water from the blood to the lumen of milk so that milk production increases. Milk lactose of ECDG, which is given $T$. diversifolia, corn waste, and CBP can bee seen in Figure 3.

\section{Milk fat}

Based on the results of this study, the ECDG milk fat content given by $T$. diversifolia, corn waste, and CBP ranged from 7.12 to $8.04 \%$, which showed no significant effect on ECDG milk fat content (Table 1). This result is higher than the research from Arief (2013), which is 3.40$5.10 \%$, Mardalena et al. (2011) 6.292-6.725\%, and Susilorini et al. (2014) 6.09-6.85\%. T. diversifolia, corn waste, and CBP increase the intake of protein in the body; one of the proteins is in the form of enzymes. Enzymes help in the process of milk fat synthesis, where enzymes are proteins. An increased protecting protein supplement increases the number of enzymes to improve the process of milk fat synthesis. One enzyme that plays a role is the enzyme xanthine oxidase. Fat content depends on the concentration of the xanthine oxidase enzyme produced by endoplasmic reticulum cell organelles. The inadequacy of this enzyme can inhibit the release of fat from the apical membrane of the mammary cell epithelium to the alveolar lumen so that the level of milk fat is reduced (Vorbach et al. 2006). The level of milk fat in goat milk by giving $T$. diversifolia, corn waste, and CBP in feed can maintain the levels of the enzyme xanthine oxidase so that it can help in the release of fat from milk cells into the alveolar lumen. 
Palm kernel cake has a high enough crude fiber content where the crude fiber consists of cellulose, hemicellulose, and lignin (Lamid et al. 2015). Crude fiber on the palm kernel cake is more easily decomposed into smaller parts because the shells of the palm kernel cake are separated so that the potential for lignin consumption by livestock is getting smaller.

It is following the argument which stated that low lignin makes organic material more easily decomposed so that it helps rumen microorganisms and digestive enzymes in digesting these materials as sources of energy (Jamarun et al. 2018). Shifting also increases the digestibility of crude fiber since it is degraded into hemicellulose and cellulose. Cellulose and hemicellulose are crude fiber, the main elements of plant cell walls, and two organic materials that are abundant in nature and potentially serve as the renewable energy source for ruminants (Lamid et al. 2015). According to Vries et al. (2012), ruminants can degrade cellulose and hemicellulose because the microbes in ruminants can produce enzymes lignocellulose.

The level of milk fat is also influenced by crude fiber and the amount of consumption of dry feed ingredients. This is in line with the opinion of Suhardi (2010), who stated that the content of crude fiber consumed greatly affects the level of milk fat produced. Milk fat levels fluctuate and are much influenced by the type of feed, especially fibrous feed. The crude fiber content of this treatment is similar so that it ultimately produces the same level of milk fat.

Digestion of crude fiber in the rumen will produce acetic acid and hydroxybutyric acid (Urrutia and Harvatine 2017), which are the main raw materials for milk synthesis. When the production of acetic acid in the rumen is reduced, it will have an impact on low levels of milk fat. In addition, the same protein content in medicine produces the same increase in the percentage of amino acids in the blood. Excess amino acids, especially those which are glucogenic, will be converted to glucose through the process of gluconeogenesis with non-hexose precursors such as glycerol, lactate, pyruvate, and glucogenic amino acids (X. Zhang et al. 2019). The use of glycerol requires active enzymes in the form of glycerol kinase so that it can be used in the mammary gland to be synthesized into milk fat. Percentage of milk fat of ECDG, which is given $T$. diversifolia, corn waste, and $\mathrm{CBP}$ can be seen in Figure 4.

\section{Dry matter and solid non-fat of milk}

The average of milk dry matter in this study is around $15.03-15.91 \%$. It is known that the treatment shows no significant difference $(\mathrm{P}>0.05)$ on the increase of dry milk ingredients. However, the total dry matter content of each treatment is higher than Indonesian National Standard, (2011). The total dry matter in milk is at least $10.8 \%$.

The significant content of milk fat in goat milk treatment is directly proportional to the total dry matter content. The difference in the total content of dry matter is also influenced by the high levels of other nutrients such as protein and lactose. Furthermore, the high total content of dry matter in milk is strongly influenced by the composition of nutrients such as fat, protein, lactose, vitamins, and minerals Dry matter milk of ECDG, which is given $T$. diversifolia, corn waste, and CBP can be seen in Figure 5.

SNF levels of dairy goat milk were not significantly affected by $T$. diversifolia, corn waste, and CBP. The level of SNF in milk is highly dependent on protein and lactose levels. Moreover, the more the protein and lactose, the higher the dry non-fat ingredients in milk (Mutamimah et al. 2013). The SNF content of goat milk in this study ranged from $7.08 \%-8.21 \%$ (Table 4); (Figure 6), based on SNI (2011) levels of SNF in milk, a minimum of 7.8\%. The result is lower than the study from Cyrilla et al. (2015), which is $9.11 \%-9.28 \%$, Yuniarti et al. (2016) $9.25 \%$ $10.02 \%$, and Badarina et al. (2015) 9.09-9.32\%. It happens due to the high difference between the levels of dry matter and milk fat. Levels of dry matter without fat are dry matter that is left after milk fat is removed. SNF levels between A, $\mathrm{B}, \mathrm{C}$, and D are not significantly different. It is because lactose and milk protein levels are also maintained to be similar so that the SNF produced is not different.

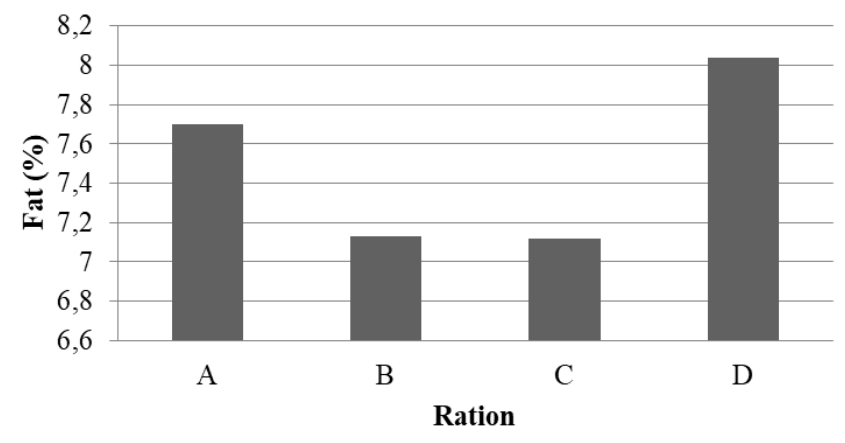

Figure 4. Milk lactose of ECDG milk which is given Tithonia diversifolia, corn waste and CBP. Note: A (60\% Tithonia diversifolia $+40 \%$ tofu-dregs), B (60\% T. diversifolia $+20 \%$ tofu-dregs $+20 \% \mathrm{CBP}), \mathrm{C}(45 \% \mathrm{~T}$. diversifolia $+15 \%$ corn waste $+20 \%$ tofu-dregs $+20 \% \mathrm{CBP}), \mathrm{D}(30 \%$ T. diversifolia + $30 \%$ corn waste $+20 \%$ tofu-dregs $+20 \%$ CBP)

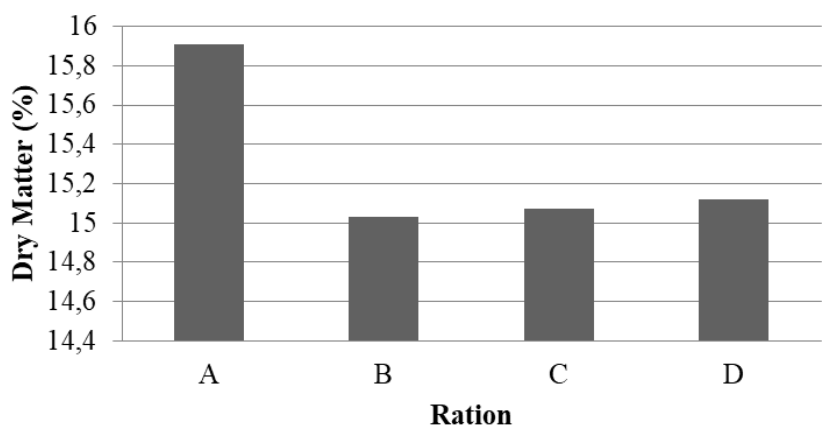

Figure 6. SNF of milk of ECDG milk which is given Tithonia diversifolia, corn waste and CBP. Note: A $(60 \%$ Tithonia diversifolia $+40 \%$ tofu-dregs), B (60\% T. diversifolia $+20 \%$ tofu-dregs $+20 \% \mathrm{CBP}), \mathrm{C}(45 \% \mathrm{~T}$. diversifolia $+15 \%$ corn waste $+20 \%$ tofu-dregs $+20 \% \mathrm{CBP}), \mathrm{D}(30 \%$ T. diversifolia + $30 \%$ corn waste $+20 \%$ tofu-dregs $+20 \%$ CBP) 
In conclusion, the research result showed that the use of Tithonia diversifolia, corn waste, and CBP could be recommended as an alternative feed without reducing milk quality of Etawa Crossbred Dairy Goat

\section{ACKNOWLEDGEMENTS}

This research was funded by Andalas University, Padang, Indonesia in accordance with the research contract No.: T/4141/UN.16.17/PP.KP-KRP2GB/LPPM/2019 for the Fiscal Year 2019.

\section{REFERENCES}

Association of Official Analytical Chemists (AOAC). 2000. Official methods of analysis. Association of Analytical Chemists. Arligton, VA.

Abdeltawab AM, Khattab MSA. 2018. Utilization of palm kernel cake as a ruminant feed for animal: A review. Asian J Biological Sci 11 (4): 157-164.

Arief, Jamarun N, Pazla R, Satria B. 2018a. Milk quality of Etawa crossbred dairy goat fed by-product of palm oil industry. Intl J Dairy Sci 13 (1): 15-21.

Arief, Elihasridas, Sowmen S, Roza E, Pazla R, Rizqan. 2018 b. Production and quality of Etawa raw milk using palm oil industry waste and paitan plants as an early feed. Pakistan J Nutr 17 (8): 399 404.

Arief, Sowmen S, Rusdimansyah, Pazla R. 2019a. Ration digestibility based on palm oil industry byproducts, Tithonia (Tithonia diversifolia) and corn waste for etawa crossbred dairy goat. Pakistan J Nutr 18 (8): 733-738.

Arief, Jamarun N, Satria B. 2019b. Response of Etawa dairy goat to provision of probiotics in ration containing by-product of palm oil industry. Adv Anim Vet Sci 7 (11): 999-1005.

Badarina I, Evvyernie D, Toharmat T, Herliyana EN, Darusman LK. 2015. Digestibility, milk production, and udder health of Etawah goat fed with fermented coffee husk. Media Peternakan 38 (1): 34-39.

Bhattarai R. 2014. Importance of goat milk. J Food Sci Technol Nepal 7:107-111.

Cyrilla L, Purwanto BP, Atabany A, Astuti DA, and Sukmawati A. 2015. Improving Milk Quality for Dairy Goat Farm Development. Media Peternakan 38 (3): 204-211.

Dharmawan R, Surjowardojo P, Susilorini TE. 2019. Effect of steaming up by gliricidia sepium to dairy goats in late gestation on milk yield and composition during the early lactation. Intl Res J Adv Eng Sci 4 (1): 290-203.

Jamarun N, Zein M, Arief, Pazla R. 2018. Populations of rumen microbes and the in vitro digestibility of fermented oil palm fronds in combination with Tithonia (Tithonia diversifolia) and elephant grass (Pennisetum purpureum). Pakistan J Nutr. 17 (1): 39-45.

Jamarun N, Pazla R, Zain M, Arief. 2019. Comparison of in vitro digestibility and rumen fluid characteristics between the Tithonia (Tithonia diversifolia) with elephant grass (Pennisetum purpureum). IOP Conf Ser J Physics Conf Ser 1469: 012004. DOI: 10.1088/1742 $6596 / 1469 / 1 / 012004$
Jamarun N, Pazla R, Zain M, Arief. 2020. Milk quality of Etawa crossbred dairy goat fed combination of fermented oil palm fronds, Tithonia (Tithonia diversifolia) and Elephant Grass (Pennisetum purpureum). IOP Conf Ser Earth Environ Sci 287: 012019. DOI: 10.1088/17551315/487/1/012019.

Lamid M, Al-Arif MA, Puspaningsih NNT, Kurniati A et. al. 2015. Lignocellulosic enzymes characterization and scanning electron microscope analysis on rice bran surface structure changes. J Chem Pharmaceut Res 7 (1): 124-130.

Mardalena, Warly L, Nurdin E, Rusmana WSN, Farizal. 2011. Milk quality of dairy goat by giving feed supplements as antioxidant sources. J Indon Trop Animal Agricult 36 (3): 205-212.

Mutamimah L, Utami, Sudewo A. 2013. Kajian kadar lemak dan bahan kering tanpa lemak susu kambing Sapera di Cilacap dan Bogor. Jurnal Ilmiah Ilmu Peternakan 1 (3): 874-880. [Indonesian]

Pazla R, Jamarun N, Zain M, Arief. 2018a. Microbial protein synthesis and in vitro fermentability of fermented oil palm fronds by Phanerochaete chrysosporium in combination with Tithonia (Tithonia diversifolia) and elephant grass (Pennisetum purpureum). Pak J Nutr 17: 462-470.

Pazla R, Zain M, Ryanti I, Dona A. 2018b. Supplementation of minerals (phosphorus and sulfur) and Saccharomyces cerevisiae in a sheep diet based on a cocoa by-product. Pak J Nut, 17: 329-335.

Sepe L, Arguello A. 2019. Recent advances in dairy goat products. AsianAustralas J Anim Sci 32 (8): 1306-1320.

Standar Nasional Indonesia (SNI). 2011. SNI 01-3141-1992 Tentang Syarat Mutu Susu Segar. Dewan Standarisasi Nasional-DSN, Jakarta. [Indonesian]

Steel RGD, Torrie JH. 2002. Principles and Procedures of Statistics: A Biometrical Approach. 3rd ed. McGraw Hill Book, New York.

Sudarmadji S, Haryono B, Suhardi. 2006. Analisa Bahan Makanan dan Pertanian. Liberty, Yogyakarta. [Indonesian]

Suranindyah YY, Dzaky HAK, Nu'man F, Rochijan. 2018. Milk production and composition of Etawah crossbred, Sapera and Saperong dairy goats in Yogyakarta, Indonesia. Int J Dairy Sci 13 (1): $1-6$.

Susilorini TE, Maylinda S, Surjowardojo P, Suyadi. 2014. Importance of body condition score for milk production traits in Peranakan Etawah goats. J Biol Agricult Healthcare 4 (3): 151-157.

Urrutia NL, Harvatine KJ. 2017. Acetate dose-dependently stimulates milk fat synthesis in lactating dairy cows. J Nutr 147 (5): 763-769.

Utari FD, Prasetiyono BWHE, Muktiani A. 2012. Kualitas susu kambing perah peranakan Ettawa yang diberi suplementasi protein terproteksi dalam wafer pakan komplit berbasis limbah agroindustri. Anim Agric J 1 (1): 427-441. [Indonesian]

Vries SD, Pustjens AM, Schols HA, Hendriks WH, Gerrits WJJ. 2012. Improving digestive utilization of fiber-rich feedstuffs in pigs and poultry by processing and enzyme technologies: A review. Anim Feed Sci Technol 178 (3-4): 123-138.

Vasudevan DM, Sreekumari S, Vaidyanathan K. 2011. Biochemistry for Medical Students. $6^{\text {th }}$ ed. Jaypee Brothers Medical Publishers (P) Ltd, New Delhi.

Vorbach C, Capecchi MR, Penninger JM. 2006. Evolusi kelenjar susu dari sistem kekebalan tubuh bawaan. BioEssays 28 (6): 606-616. [Indonesian]

Yuniarti E, Evvyernie D, Astuti DA. 2016. Production and energy partition of lactating dairy goats fed rations containing date fruit waste. Media Peternakan 39 (1): 27-30.

Zhang Y, Zhang S, Guan W, Chen F, Cheng L, Lv Y, Chen J. 2018. GLUT1 and lactose synthetase are critical genes for lactose synthesis in lactating sows. Nutr Metabolism 15 (40): 2-13.

Zhang X, Yang S, Chen J, Su Z. 2019. Unraveling the regulation of hepatic gluconeogenesis. Front Endocrinol (Lausanne) 9 (802): 1-18. 